\title{
H19 gene polymorphisms and Wilms tumor risk in Chinese children: a four-center case-control study
}

\author{
Wenya Li \\ Zhengzhou University First Affiliated Hospital https://orcid.org/0000-0001-6638-8675 \\ Rui-Xi Hua \\ Sun Yat-sen University First Affiliated Hospital \\ Mi Wang \\ Guangzhou Women and Children's Medical Center \\ Da Zhang \\ Zhengzhou University First Affiliated Hospital \\ Jinhong Zhu \\ Guangzhou Women and Children's Medical Center \\ Songyang Zhang \\ Zhengzhou University First Affiliated Hospital \\ Yang Yang \\ Zhengzhou University First Affiliated Hospital \\ Jiwen Cheng \\ Xi'an Jiaotong University Second Affiliated Hospital \\ Haixia Zhou \\ Wenzhou Medical University Second Affiliated Hospital and Yuying Children's hospital \\ Jiao Zhang ( $\nabla$ fcczhangj7@zzu.edu.cn ) \\ https://orcid.org/0000-0002-4977-263X \\ Jing He \\ Guangzhou Women and Children's Medical Center
}

\section{Research article}

Keywords: H19, polymorphism, Wilms tumor, susceptibility

Posted Date: June 8th, 2020

DOI: https://doi.org/10.21203/rs.2.23509/v2

License: (a) (1) This work is licensed under a Creative Commons Attribution 4.0 International License. Read Full License

Version of Record: A version of this preprint was published at Molecular Genetics \& Genomic Medicine on January 5th, 2021. See the published version at https://doi.org/10.1002/mgg3.1584. 


\section{Abstract}

Background Wilms tumor is the most common pediatric renal cancer. However, genetic bases behind Wilms tumor remain largely unknown. $\mathrm{H} 19$ is a critical maternally imprinted gene. Previous studies indicated that nucleotide polymorphisms (SNPs) in the H19 can modify the risk of several human malignancies. Epigenetic errors at the $H 19$ locus lead to biallele silencing in Wilms tumors. Genetic variations in the $H 19$ may be related to Wilms tumor susceptibility.

Methods We conducted a four-center study to investigate whether H19 SNPs was a predisposing factor to Wilms tumor. Three polymorphisms in the $H 19$ (rs2839698 G>A, rs3024270 C>G, rs217727 G>A) were genotyped in 355 cases and 1070 cancer-free controls, using Taqman method. Odds ratios (ORs) and 95\% confidence intervals (Cls) were calculated to evaluate the strength of the associations.

Results We found that all of these three polymorphisms were significantly associated with Wilms tumor risk alterations. Carriers of 1,2 and 1-2 risk genotypes were inclined to develop Wilms tumor compared with those without risk genotype (adjusted OR=1.36, 95\% $\mathrm{Cl}=1.02-1.80, P=0.037$; adjusted $\mathrm{OR}=1.84,95 \% \mathrm{Cl}=1.27-2.67, P=0.001$; adjusted $\mathrm{OR}=1.50,95 \% \mathrm{Cl}=1.17-1.92, P=0.002$, respectively). The stratified analysis further revealed that rs2839698 AA, rs217727 AA, and 1-2 risk genotypes could strongly increase Wilms tumor risk among male patients above 18 months of age.

Conclusion Our findings indicate that genetic variations in the $\mathrm{H19}$ may confer Wilms tumor risk.

\section{Background}

Wilms tumor, also known as nephroblastoma, is derived from the pluripotent embryonic kidney precursor. Wilms tumor is the most common renal malignancy in children, accounting for $85 \%$ of pediatric renal tumors [1-3]. It is characterized by early diagnosis and male predominance worldwide, with incidence varying by race [4]. The prevalence of Wilms tumor is similar in black and white children [5], but is around half in East Asian children, about three per million [4]. In China, the frequency of Wilms tumor is around 3.3 per million, ranking the fifth in the incidence of malignant tumors in children aged 0 to 4 years [6]. Besides, about 1-3\% of Wilms tumor have a family history, probably due to rare germline mutations and incomplete expressiveness [7]. Environmental factors and immigration factors seem not to play a prominent role in etiology $[1,4,8]$. The survival rate of Wilms tumor is more than $90 \%$ after excluding some high-risk cases with anaplastic histology, bilateral lesions and recurrent diseases [9]. However, up to $25 \%$ of survivors reported severe chronic health problems [10]. Moreover, late diagnosis and high recurrence rates in patients are reported in underdeveloped regions [11], based on the difficulty of stratification of increasingly refined tumor subtypes and the high cost of chemoradiotherapy for high-risk tumors [9]. Therefore, to improve the outcomes, it is of great significance to enhance prevention and early diagnosis by developing accurate biomarkers to identify high-risk individuals.

As a critical maternally imprinted gene, the $\mathrm{H} 19$ was discovered successively in different laboratories in the 1980 s. This gene located on chromosome 11p15.5 in humans is composed of five exons and four introns [12]. The expression of HI9 is highly increased in many embryos and decreased after birth [13]. HI9 gene encodes a long non-coding RNA, which may have tumor-inhibiting functions [14]. More and more evidence indicates that the $\mathrm{H} 19$ gene is essential for human tumor growth from different biological processes [15]. Studies have shown that the $\mathrm{H} 19$ gene was upregulated in lung cancer, gastric cancer, colon cancer, retinoblastoma, thyroid cancer and breast cancer [15-20]. However, the up-regulated expression of the $\mathrm{H19}$ gene can inhibit pituitary tumor cell proliferation in vitro and in vivo [21]. Consistently, H19 gene expression decreased in most hepatoblastomas [22]. Studies have shown that epigenetic errors at the $\mathrm{H} 19$ gene site in early embryonic development may result in the silencing of the double-alleles in Wilms tumor, thereby affecting the imprinting of parental alleles [23]. Matthew K lyer et al. found many IncRNAs overlapping disease-associated SNPs [24]. Previous genomics studies have demonstrated that SNPs in several genes are associated with the risk of Wilms tumor [25-27]. It has been reported that $H 19$ rs2839698 G>A, rs3024270 C>G or rs217727 G>A polymorphism is not associated with neuroblastoma susceptibility in the whole study population, while in stratified analysis, girls with rs3024270 GG genotype had an increased risk of neuroblastoma [28]. To date, no publication has been reported on the association between $H 19$ gene polymorphisms and Wilms tumor susceptibility. In this study, we scrutinized the association of several H19 gene SNPs (rs2839698, rs3024270, and rs217727) and Wilms tumor risks based on a four-center study of Chinese children.

\section{Methods}




\section{Study subjects}

The cases were enrolled in this project according to previously reported criteria [29-31]. In brief, 355 Wilms tumor cases and 1,070 healthy controls were included in this study (Supplemental Table 1). The 355 cases were from four medical centers (Guangzhou Women and Children's Medical Center, The First Affiliated Hospital of Zhengzhou University, The Second Affiliated Hospital and Yuying Children's Hospital of Wenzhou Medical University, and Second Affiliated Hospital of Xi'an Jiao Tong University). All the control groups were selected from the same region as cases during the same period. Patients' age, sex, and clinical stages were collected by trained medical staff. We conducted this study following the approval of the Institutional Review Board of the participating hospitals. All the participants' parents provided signed informed consent before the examination.

\section{Polymorphism analysis}

Each subject donated about $2 \mathrm{~mL}$ of peripheral blood for DNA extraction using a TIANamp Blood DNA Kit (TianGen Biotech Co. Ltd., Beijing, China). Three $H 19$ gene polymorphisms (rs2839698 G>A, rs3024270 C>G, rs217727 G>A) were chosen for genotyping by $A B I$ Taqman probe (Applied Biosystems, Foster City, CA) [28]. We genotyped the gene polymorphisms using Taqman real-time PCR [32, 33]. The randomized and blinded process method was adopted while genotyping all samples. Approximately $10 \%$ random selection samples were re-genotyped, and the genotype concordance rate was $100 \%$.

\section{Statistical analysis}

Departures from Hardy-Weinberg equilibrium (HWE) for the selected SNPs in controls were evaluated using a goodness-of-fit $\chi^{2}$ test. Allele frequencies and demographic variables between the two groups were assessed by the $\chi^{2}$ test. Risk associations between genotypes and Wilms tumor were determined from a logistic regression analysis. The ORs, $95 \% \mathrm{Cls}$, and the corresponding $P$ value for each SNP were calculated with adjustment for age and gender. All statistical calculations were implemented with the utilization of SAS software version 9.4 (SAS Institute, Cary, NC). Two-sided statistical tests were employed in this study. The significance threshold was defined as $P<0.05$.

\section{Results}

\section{Associations between $\mathrm{H} 19$ gene polymorphisms and Wilms tumor susceptibility}

The detailed characteristics of all the subjects were shown in Supplementary Table 1. A total of 355 patients and 1068 healthy controls were successfully genotyped. The genotype frequencies of the three selected $\mathrm{H} 19$ gene polymorphisms and their associations with Wilms tumor susceptibility were presented in Table 1 . We observed the genotype frequency distributions of the selected $H 19$ gene polymorphisms were no significant deviation with the Hardy-Weinberg equilibrium ( $P=0.245$ for rs2839698 $G>A, P=0.138$ for rs3024270 C>G, $P=0.992$ for rs $217727 \mathrm{G}>\mathrm{A}$ polymorphism) in controls. In single-locus analysis, we observed that all three polymorphisms were significantly associated with Wilms tumor risk individually. Specifically, the risk estimates for the these SNPs were as follows: the rs $2839698 \mathrm{G}>\mathrm{A}$ polymorphism ( $\mathrm{AG}$ vs. GG: adjusted $\mathrm{OR}=0.74,95 \% \mathrm{Cl}=0.57-0.96, P=0.024$; $\mathrm{AA}$ vs. GG: adjusted $\mathrm{OR}=1.52,95 \% \mathrm{Cl}=1.05-2.22, P=0.027$; $A A$ vs. $\mathrm{GG} / \mathrm{AG}$ : adjusted $\mathrm{OR}=1.75,95 \% \mathrm{Cl}=1.23-2.50, P=0.002)$, the rs $3024270 \mathrm{C}>\mathrm{G}$ polymorphism (CG vs. $\mathrm{CC}$ : adjusted $\mathrm{OR}=0.61,95 \% \mathrm{Cl}=0.46-0.81, P=0.0007 ; \mathrm{CG} / \mathrm{GG}$ vs. $\mathrm{CC}$ : adjusted $\mathrm{OR}=0.73,95 \% \mathrm{Cl}=0.57-0.95$, $P=0.018 ; \mathrm{GG}$ vs. $\mathrm{CC} / \mathrm{CG}$ : adjusted $\mathrm{OR}=1.38,95 \% \mathrm{Cl}=1.05-1.82, P=0.023$ ), and the rs217727 polymorphism (AG vs. GG: adjusted $\mathrm{OR}=0.76,95 \% \mathrm{Cl}=0.58-0.99, P=0.035)$. 
ble 1. Associations between $H 19$ polymorphisms and Wilms tumor risk

\begin{tabular}{|c|c|c|c|c|c|c|c|}
\hline notype & $\begin{array}{l}\text { Cases } \\
(\mathrm{N}=355)\end{array}$ & $\begin{array}{l}\text { Controls } \\
(\mathrm{N}=1068)\end{array}$ & $P^{\mathrm{a}}$ & $\begin{array}{l}\text { Crude OR } \\
(95 \% \text { CI })\end{array}$ & $P$ & $\begin{array}{l}\text { Adjusted OR } \\
(95 \% \mathrm{CI})^{\mathrm{b}}\end{array}$ & $P^{\mathrm{b}}$ \\
\hline \multicolumn{8}{|c|}{$2839698(\mathrm{HWE}=0.245)$} \\
\hline iG & $174(49.01)$ & $488(45.69)$ & & 1.00 & & 1.00 & \\
\hline$G$ & $127(35.77)$ & $480(44.94)$ & & $0.74(0.57-0.96)$ & 0.025 & $0.74(0.57-0.96)$ & 0.024 \\
\hline A & $54(15.21)$ & $100(9.36)$ & & $1.52(1.04-2.20)$ & 0.029 & $1.52(1.05-2.22)$ & 0.027 \\
\hline dditive & & & 0.0008 & $1.06(0.89-1.27)$ & 0.537 & $1.06(0.89-1.27)$ & 0.530 \\
\hline Iominant & $181(50.99)$ & $580(54.31)$ & 0.277 & $0.88(0.69-1.11)$ & 0.277 & $0.88(0.69-1.11)$ & 0.275 \\
\hline ecessive & $301(84.79)$ & $968(90.64)$ & 0.002 & $1.74(1.22-2.48)$ & 0.002 & $1.75(1.23-2.50)$ & 0.002 \\
\hline \multirow{2}{*}{ קחת } & $475(66.90)$ & $1456(68.16)$ & & 1.00 & & 1.00 & \\
\hline & 235 (33.10) & $680(31.84)$ & 0.532 & $1.06(0.89-1.27)$ & 0.532 & $1.06(0.89-1.27)$ & 0.526 \\
\hline \multicolumn{8}{|c|}{$3024270(\mathrm{HWE}=0.138)$} \\
\hline C & $120(33.80)$ & $290(27.15)$ & & 1.00 & & 1.00 & \\
\hline 'G & 141 (39.72) & $556(52.06)$ & & $0.61(0.46-0.81)$ & 0.0007 & $70.61(0.46$ & 0.0007 \\
\hline iG & $94(26.48)$ & $222(20.79)$ & & $1.02(0.74-1.41)$ & 0.888 & $1.03(0.75-1.42)$ & 0.861 \\
\hline dditive & & & 0.0003 & $0.98(0.83-1.16)$ & 0.826 & $0.98(0.83-1.17)$ & 0.852 \\
\hline Iominant & 235 & 72.85) & 0.017 & $0.73(0.56-0.95)$ & 0.017 & $0.73(0.57-0.95)$ & 0.018 \\
\hline ecessive & $261(73.52)$ & $846(79.21)$ & 0.025 & $1.37(1.04-1.81)$ & 0.026 & $1.38(1.05-1.82)$ & 0.023 \\
\hline & 381 (53.66) & $1136(53.18)$ & & .00 & & 1.00 & \\
\hline & $329(46.34)$ & $1000(46.82)$ & 0.825 & $83-1.16)$ & 0.825 & $0.98(0.83-1.17)$ & 0.850 \\
\hline \multicolumn{8}{|c|}{$217727(\mathrm{HWE}=0.992)$} \\
\hline iG & $177(49.86)$ & $486(45.51)$ & & 1.00 & & 1.00 & \\
\hline G & 130 (36.62) & 469 (43.91) & & $0.76(0.59-0.99)$ & 0.039 & $0.76(0.58-0.99)$ & 0.035 \\
\hline A & $48(13.52)$ & $113(10.58)$ & & $1.17(0.80-1.70)$ & 0.426 & $1.17(0.80-1.71)$ & 0.421 \\
\hline dditive & & & 0.039 & $0.97(0.81-1.16)$ & 0.733 & $0.97(0.81-1.16)$ & 0.719 \\
\hline rominant & $178(50.14)$ & $582(54.49)$ & 0.154 & $0.84(0.66-1.07)$ & 0.155 & $0.84(0.66-1.06)$ & 0.144 \\
\hline ecessive & 307 & 955 (89.42) & 0.130 & $1.32(0.92-1.90)$ & 0.131 & $1.33(0.93-1.91)$ & 0.124 \\
\hline 1 & 484 (68.17) & $1441(67.46)$ & & 1.00 & & 1.00 & \\
\hline & 226 (31.83) & $695(32.54)$ & 0.728 & $0.97(0.81-1.16)$ & 0.728 & $0.97(0.81-1.16)$ & 0.714 \\
\hline \multicolumn{8}{|c|}{ mbined effect of risk genotypes ${ }^{\mathrm{C}}$} \\
\hline & 211 (59.44) & 732 (68.54) & & 1.00 & & 1.00 & \\
\hline & $92(25.92)$ & 237 (22.19) & & $1.35(1.01-1.79)$ & 0.041 & $1.36(1.02-1.80)$ & 0.037 \\
\hline & $52(14.65)$ & 99 (9.27) & & $1.82(1.26-2.64)$ & 0.001 & $1.84(1.27-2.67)$ & 0.001 \\
\hline rend & & & 0.002 & $1.35(1.14-1.60)$ & 0.0005 & $51.36(1.15-1.61)$ & 0.0004 \\
\hline & 211 (59.44) & $732(6$ & & 1.00 & & 1.00 & \\
\hline-2 & $144(40.56)$ & $336(31.46)$ & 0.002 & $1.49(1.16-1.91)$ & 0.002 & $1.50(1.17-1.92)$ & 0.002 \\
\hline
\end{tabular}

2 test for genotype distributions between Wilms tumor patients and controls.

ıdjusted for age and gender.

Risk genotypes were carriers with rs2839698 AA, rs3024270 GG and rs217727 AA genotypes.

While analyzing the combined effect of risk genotypes, we found that subjects carrying 1 or 2 risk genotypes had a significantly increased Wilms tumor risk when compared with those without risk genotypes (adjusted $\mathrm{OR}=1.36,95 \% \mathrm{Cl}=1.02-1.80, P=0.041$; and adjusted $\mathrm{OR}=1.84,95 \% \mathrm{Cl}=1.27-2.67, P=0.001)$. Moreover, we found that subjects with 1-2 risk genotypes were significantly more likely to develop Wilms tumor than subjects carrying no risk genotypes (adjusted $\mathrm{OR}=1.50,95 \% \mathrm{Cl}=1.17-1.92, P=0.002$ ).

\section{Stratification analysis}

We then performed a stratified analysis to explore how age, gender, and clinical stage influence the association between selected polymorphisms and Wilms tumor susceptibility (Table 2). Compared to the rs2839698 GG/AG genotype, the risk effects of AA genotype was more predominant in children above 18 months of age (adjusted $\mathrm{OR}=1.73 ; 95 \% \mathrm{Cl}=1.09-2.74, P=0.020$ ), female (adjusted $\mathrm{OR}=1.94,95 \% \mathrm{Cl}=1.11-3.39, P=0.021$ ), male (adjusted $\mathrm{OR}=1.63,95 \% \mathrm{Cl}=1.02-2.58, P=0.040$ ), and those with clinical stage $\mathrm{I}+\mathrm{Il}$ disease (adjusted $\mathrm{OR}=1.83,95 \% \mathrm{Cl}=1.20-2.79, P=0.005$ ). Consistently, with the rs217727 GG/AG genotype as references, AA genotype carriers was associated with an increased risk of Wilms tumor for children above 18 months of age (adjusted OR=1.65; 95\% $\mathrm{Cl}=1.06$ 2.58, $P=0.027$ ), male (adjusted $\mathrm{OR}=1.60,95 \% \mathrm{Cl}=1.01-2.54, P=0.047$ ), clinical stage $++\mid l$ cases (adjusted $\mathrm{OR}=1.60,95 \% \mathrm{Cl}=1.05-2.44$, $P=0.029)$. However, no association was observed between rs3024270 and Wilms tumor susceptibility in subgroups defined by age, sex, and clinical stages.

We also interrogated the cumulative effects of these SNPs on Wilms tumor risk in the stratified analysis. We found that the presence of 1-2 risk genotypes was significantly associated with the risk of Wilms tumor in children above 18 months of age (adjusted OR=1.66; $95 \% \mathrm{Cl}=1.21-2.27, P=0.002$ ), male (adjusted $\mathrm{OR}=1.59,95 \% \mathrm{Cl}=1.14-2.21, P=0.006$ ), and clinical stage $\mathrm{I}+\mathrm{ll}$ patients (adjusted $\mathrm{OR}=1.64$, $95 \% \mathrm{Cl}=1.21-2.22, P=0.002)$ when compared with those of 0 risk genotype.

\section{Discussion}


Table 2. Stratification analysis for association between $H 19$ genotypes and Wilms tumor susceptibility.

\begin{tabular}{|c|c|c|c|c|c|c|c|c|c|c|c|c|c|c|c|c|}
\hline \multirow[t]{2}{*}{$\overline{\text { Variables }}$} & \multicolumn{2}{|c|}{$\begin{array}{l}\text { rs2839698 } \\
\text { (case/control) }\end{array}$} & \multirow{2}{*}{$\begin{array}{l}\text { Adjusted } \\
\text { OR }^{\mathrm{a}} \\
(95 \% \\
\text { CI) }\end{array}$} & \multirow{2}{*}{$P^{\mathrm{a}}$} & \multicolumn{2}{|c|}{$\begin{array}{l}\text { rs3024270 } \\
\text { (case/control) }\end{array}$} & \multirow{2}{*}{$\begin{array}{l}\text { Adjusted } \\
\text { OR }^{\mathrm{a}} \\
(95 \% \\
\mathrm{CI}) \\
\end{array}$} & \multirow{2}{*}{$P^{\mathrm{a}}$} & \multicolumn{2}{|c|}{$\begin{array}{l}\text { rs217727 } \\
\text { (case/control) }\end{array}$} & \multirow{2}{*}{$\begin{array}{l}\text { Adjusted } \\
\text { OR }^{\mathrm{a}} \\
(95 \% \\
\mathrm{CI}) \\
\end{array}$} & \multirow{2}{*}{$P^{\mathrm{a}}$} & \multicolumn{2}{|c|}{$\begin{array}{l}\begin{array}{l}\text { Risk genotypes } \\
\text { (case/control) }\end{array} \\
\end{array}$} & \multirow{2}{*}{$\begin{array}{l}\text { Adjusted } \\
\text { OR }^{\mathrm{a}} \\
(95 \% \\
\mathrm{CI}) \\
\end{array}$} & \multirow{2}{*}{$P^{\mathrm{a}}$} \\
\hline & $\overline{\mathrm{GG} / \mathrm{AG}}$ & AA & & & $\overline{\mathrm{CC} / \mathrm{CG}}$ & GG & & & $\overline{\mathrm{GG} / \mathrm{AG}}$ & AA & & & $\overline{0}$ & $1-2$ & & \\
\hline \multicolumn{17}{|c|}{ Age, month } \\
\hline$\leq 18$ & $104 / 382$ & $21 / 43$ & $\begin{array}{l}1.76 \\
(0.99- \\
3.10)\end{array}$ & 0.052 & $92 / 335$ & $33 / 90$ & $\begin{array}{l}1.32 \\
(0.84- \\
2.10)\end{array}$ & 0.233 & $112 / 375$ & $13 / 50$ & $\begin{array}{l}0.85 \\
(0.45- \\
1.63)\end{array}$ & 0.629 & $77 / 284$ & $48 / 141$ & \multirow{2}{*}{$\begin{array}{l}1.24 \\
(0.82- \\
1.87) \\
1.66 \\
(1.21- \\
2.27)\end{array}$} & 0.315 \\
\hline$>18$ & $197 / 586$ & $33 / 57$ & $\begin{array}{l}1.73 \\
(1.09- \\
2.74)\end{array}$ & 0.020 & $169 / 511$ & $61 / 132$ & $\begin{array}{l}1.41 \\
(0.99- \\
2.01)\end{array}$ & 0.054 & $=195 / 580$ & $35 / 63$ & $\begin{array}{l}1.65 \\
(1.06- \\
2.58)\end{array}$ & 0.027 & $134 / 448$ & 96/195 & & 0.002 \\
\hline \multicolumn{17}{|l|}{ Gender } \\
\hline Female & $140 / 412$ & $23 / 35$ & $\begin{array}{l}1.94 \\
(1.11- \\
3.39)\end{array}$ & 0.021 & $121 / 361$ & $42 / 86$ & $\begin{array}{l}1.46 \\
(0.96- \\
2.23)\end{array}$ & 0.080 & $146 / 400$ & $17 / 47$ & $\begin{array}{l}0.99 \\
(0.55- \\
1.79)\end{array}$ & 0.982 & $103 / 314$ & 60/133 & \multirow{2}{*}{$\begin{array}{l}1.38 \\
(0.95- \\
2.01) \\
1.59 \\
(1.14- \\
2.21)\end{array}$} & 0.096 \\
\hline Male & $161 / 556$ & $31 / 65$ & $\begin{array}{l}1.63 \\
(1.02- \\
2.58)\end{array}$ & 0.040 & $140 / 485$ & $52 / 136$ & $\begin{array}{l}1.32 \\
(0.91- \\
1.91)\end{array}$ & 0.144 & $=161 / 555$ & $31 / 66$ & $\begin{array}{l}1.60 \\
(1.01- \\
2.54)\end{array}$ & 0.047 & $108 / 418$ & $84 / 203$ & & 0.006 \\
\hline \multicolumn{17}{|c|}{ Clinical stage } \\
\hline $\mathrm{I}+\mathrm{II}$ & $117 / 968$ & $34 / 100$ & $\begin{array}{l}1.83 \\
(1.20- \\
2.79)\end{array}$ & 0.005 & $156 / 846$ & $55 / 222$ & $\begin{array}{l}1.35 \\
(0.95- \\
1.89)\end{array}$ & 0.091 & $178 / 955$ & $33 / 113$ & $\begin{array}{l}1.60 \\
(1.05- \\
2.44)\end{array}$ & 0.029 & $121 / 732$ & $90 / 336$ & \multirow{2}{*}{$\begin{array}{l}1.64 \\
(1.21- \\
2.22) \\
1.17 \\
(0.79- \\
1.73) \\
\end{array}$} & 0.002 \\
\hline III+IV & $108 / 968$ & $18 / 100$ & $\begin{array}{l}1.66 \\
(0.96- \\
2.85) \\
\end{array}$ & 0.069 & $93 / 846$ & $33 / 222$ & $\begin{array}{l}1.36 \\
(0.89- \\
2.07) \\
\end{array}$ & 0.161 & $115 / 955$ & $11 / 113$ & $\begin{array}{l}0.81 \\
(0.42- \\
1.55) \\
\end{array}$ & 0.523 & $82 / 732$ & 44/336 & & 0.423 \\
\hline
\end{tabular}

a Adjusted for age and gender, omitting the corresponding stratify factor.

In the current hospital-based case-control study, we demonstrated the association of three H19 gene polymorphisms with Wilms tumor susceptibility.This article was the first report indicating that H19 SNPs were related to Wilms tumor risk.

The genetic changes that underpin Wilms tumor are diverse, many studies have defined cancer genes that harbor likely driver mutations [34]. H19 is found in an imprinted region of chromosome 11, contains five exons and four small introns, and the three SNPs rs2839698, rs3024270 and rs217727 located in exon 1, intron and exon 5, respectively [35]. DNA methylation influences gene expression and protein levels through epigenetic modification, thereby promoting the development of various diseases [36].

Differentially methylated regions (DMRs) are generally considered CpG rich, usually are associated with the genetic or epigenetic modifications. The H19 DMR located upstream of the transcription initiation site regulates its gene activity [37]. It is well known that hypermethylation of H19 DMR, lead to the expression of biallelic IGF2, which is an important step in Wilms tumorigenesis [38]. A recent literature showed that hypermethylation of the $\mathrm{H} 19$ locus occurred in premalignant kidney cells, revealed the driving factors of Wilms tumor [39]. The genotype-specific methylation changes at the H19 ICR in assisted reproductive technology derived placentas is associated with the polymorphism rs10732516 [40]. It has also been reported hypomethylation status in promoter region of $H 19$ gene indicated a higher risk of preeclampsia, H19 mRNA expression was higher in recessive model, but there was no association between mRNA expression and placental $H 19$ associated polymorphisms [35]. This may suggest that the effect of $H 19$ risk SNPs on DNA methylation in Wilms tumor.

Non-coding RNAs are known to play central roles in the dynamic control of transcriptional and gene expression [41]. LncRNAs contribute to the pathogenesis of various cancers by participating in the control of cell cycle, proliferation, differentiation, and apoptosis [42, 43]. H19 gene is the only imprinted gene that can encode IncRNA and play a role in the mRNA level [44]. So far, 10 polymorphisms in $\mathrm{H} 19$ have been identified as predisposing factors to various cancer types, among which the rs 217727 has been most frequently studied, followed by rs2839698 [45]. H19 plays an essential role in the tumor progression of breast cancer [15], bladder cancer [46], gastric cancer [17], and other tumors [20,47,48], other than that, mutations in the H19 gene coding sequence are also closely related to tumors, despite unknown regulatory mechanisms [12,49]. The following evidence suggests that SNPs may affect the expression and function of the $H 19$ gene. The rs 2839698 polymorphism may influence the folding structures of IncRNA $H 19$ and change the target microRNAs of IncRNA H19, thereby increasing the risk of colorectal cancer [50]. Verhaegh et al. found that the folding structure of rs217727 and rs2839698 of IncRNA H19 was different under TT and CC genotypes, and both the T and C genotype of them had a significantly decreased risk of bladder cancer [51]. What's more, the rs217727 CT+TT genotype was associated with a lower risk of breast cancer in women who were pregnant more than twice [52]. The above results indicated that the H19 gene encoding the SNP altering the biological characteristics of IncRNA H19 and the occurrence and development of tumors. The IncRNA H19 could be a potential diagnostic and prognostic marker in the development of tumors [53], and the different genotypes of SNPs might facilitate an individualized diagnosis of cancer. 
There are other explanations of the relationship between IncRNA H19 and tumors. The miR675 signal axis plays a vital role in tumorigenesis, which is a microRNA, embedded in the $H 19$ gene's first exon [54]. Li et al. first demonstrated that miR675 promoted liver carcinogenesis through the cascade of miR675-HP1a-EGR1-H19-PKM2 signaling and clearly demonstrated that miR675 overexpression stimulated liver cancer cell growth, vice versa [55]. Wu et al. revealed that IncRNA H19 promoted laryngeal squamous cell carcinoma (LSCC) progression via miR-148a-3p and DNMT1, indicating that H19 plays the role of microRNA sponge in promoting tumor development [56]. Another study suggested that the effect of $H 19$ in GC is mediated by the direct upregulation of ISM1 and the indirect suppression of CALN1 expression via miR-675 [57]. Additionally, functional SNP rs217727 in H19 is highly likely to be involved in breast cancer development in hormone-signaling pathways [58].

In stratified analysis, Wilms tumor risk of rs2839698 variant AA genotypes was more evident in subgroups of age above 18 months, female, male, and clinical stage I+II cases. The same genotype is also associated with an increased risk of gastrointestinal cancer [45]. Similar results were obtained in rs 217727 AA except in gender considerations, only males. In addition, previous data showed that stratified analysis of rs $217727 \mathrm{C}>\mathrm{T}$ showed both dominant and recessive effects associated with increased risk of oral squamous cell carcinoma (OSCC) and lung cancer [45]. Our results further revealed the critical influence of G and A genotype in H19 rs217727. In line with our observations, the study has revealed that the carriers of rs217727 AA genotype had a significantly increased risk of bladder cancer in young male patients [59]. Studies demonstrated T variant of rs217727 was strongly associated with an increased risk of coronary artery disease (CAD) and gastric cancer (GC) $[60,61]$. These facts may partially explain the apparent imbalance of the analyzed SNPs. We did not find any associations between the rs3024270 genotype and Wilms tumor in stratified analysis.

There are potential limitations of the current study: 1 ) the relatively small sample size and lacking participants from different ethnic groups, 2) the consideration of only three polymorphisms without potential function, and 3) unknown living environmental factors on.

\section{Conclusion}

we verified that the rs2839698 G>A, rs3024270 C>G, rs217727 G>A polymorphisms were significantly associated with the risk of Wilms tumor. Further stratified data showed that older children, early clinical stage and gender were risk factors. These results reveal the intricacy of $\mathrm{H} 19$ functions and the dual role of $\mathrm{H} 19$ polymorphisms in the development of Wilms tumors. Thus, the results of our study should be verified in studies with larger samples from different ethnicities.

\section{Abbreviations}

SNP: Single nucleotide polymorphism; OR: Odds ratio; Cl: confidence interval; HWE: Hardy-Weinberg equilibrium; PCR: Polymerase chain reaction; IncRNA: long non-coding RNA

\section{Declarations}

\section{Ethics approval and consent to participate}

The study was approved by the Institutional Review Board of the participating hospitals. All the participants' parents provided signed informed consent before the examination.

\section{Consent for publication}

Not applicable.

\section{Availability of data and materials}

The datasets during and/or analysed during the current study available from the corresponding author on reasonable request.

\section{Competing interests}

The authors declare that they have no competing interests.

\section{Funding}


This study was supported by grants from the National Natural Science Foundation of China (No: 81502187, Grantee: Jiao Zhang), Henan Province Key Scientific Research Projects of Colleges and Universities in 2020 (No: 20A320020, Grantee: Jiao Zhang), Henan Province Key Research and Development and Promotion Project (Scientific and Technological Research) in 2019 (No: 192102310377, Grantee: Jiao Zhang), the Pearl River S\&T Nova Programme of Guangzhou (No: 201710010086, Grantee: Jing He), and Guangdong Provincial Key Laboratory of Research in Structural Birth Defect Disease (No: 2019B030301004, Grantee: Jing He). The founders had no role in study design, data collection and analysis, decision to publish, or preparation of the manuscript.

\section{Authors' contributions}

WYL囚RXH and MW designed and organized the manuscript. DZ, JHZ囚SYZ『YY, JWC and HXZ collected and analysed the data. JZ and $\mathrm{JH}$ reviewed the papers and revised the manuscript. All the authors have read and approved the final version of the manuscript and agree to be accountable for all aspects of the work.

\section{Acknowledgements}

We thank Guangzhou Women and Children's Medical Center, The First Affiliated Hospital of Zhengzhou University, The Second Affiliated Hospital, and Yuying Children's Hospital of Wenzhou Medical University, and Second Affiliated Hospital of Xi'an Jiao Tong University for providing blood samples from patients for genetic research purposes.

\section{ORCID}

Jing He, https://orcid.org/0000-0002-1954-2892

Wenya Li, https://orcid.org/0000-0001-6638-8675

\section{References}

1. Birch JM, Breslow N. Epidemiologic features of Wilms tumor. Hematol Oncol Clin North Am. 1995;9(6):1157-78. Epub 1995/12/01.

2. Rivera MN, Haber DA. Wilms' tumour: connecting tumorigenesis and organ development in the kidney. Nat Rev Cancer. 2005;5(9):699-712. Epub 2005/08/20. doi: 10.1038/nrc1696.

3. Vujanic GM, Sandstedt B. The pathology of Wilms' tumour (nephroblastoma): the International Society of Paediatric Oncology approach. Journal of Clinical Pathology. 2010;63(2):102-9. doi: 10.1136/jcp.2009.064600.

4. Fukuzawa R, Reeve AE. Molecular pathology and epidemiology of nephrogenic rests and Wilms tumors. J Pediatr Hematol Oncol. 2007;29(9):589-94. Epub 2007/09/07. doi: 10.1097/01.mph.0000212981.67114.ec.

5. Breslow N, Olshan A, Beckwith JB, Moksness J, Feigl P, Green D. Ethnic variation in the incidence, diagnosis, prognosis, and followup of children with Wilms' tumor. J Natl Cancer I. 1994;86(1):49-51. doi: 10.1093/jnci/86.1.49.

6. Bao PP, Li K, Wu CX, et al. [Recent incidences and trends of childhood malignant solid tumors in Shanghai, 2002-2010]. Zhonghua Er Ke Za Zhi. 2013;51(4):288-94. Epub 2013/08/10.

7. Chu AN, Heck JE, Ribeiro KB, et al. Wilms' tumour: a systematic review of risk factors and meta-analysis. Paediatr Perinat Ep. 2010;24(5):449-69. doi: 10.1111/j.1365-3016.2010.01133.x.

8. Bunin GR, Meadows AT. Epidemiology and Wilms tumor: approaches and methods. Med Pediatr Oncol. 1993;21(3):169-71. Epub 1993/01/01. doi: 10.1002/mpo.2950210304.

9. Dome JS, Graf N, Geller JI, et al. Advances in Wilms Tumor Treatment and Biology: Progress Through International Collaboration. J Clin Oncol. 2015;33(27):2999-3007. Epub 2015/08/26. doi: 10.1200/JC0.2015.62.1888.

10. van Waas M, Neggers SJ, Raat H, van Rij CM, Pieters R, van den Heuvel-Eibrink MM. Abdominal radiotherapy: a major determinant of metabolic syndrome in nephroblastoma and neuroblastoma survivors. Plos One. 2012;7(12):e52237. Epub 2012/12/20. doi: 10.1371/journal.pone.0052237.

11. Phelps HM, Al-Jadiry MF, Corbitt NM, et al. Molecular and epidemiologic characterization of Wilms tumor from Baghdad, Iraq. World J Pediatr. 2018;14(6):585-93. Epub 2018/08/30. doi: 10.1007/s12519-018-0181-3.

12. Gabory A, Jammes H, Dandolo L. The H19 locus: role of an imprinted non-coding RNA in growth and development. Bioessays. 2010;32(6):473-80. Epub 2010/05/21. doi: 10.1002/bies.200900170.

Page $7 / 10$ 
13. Lustig-Yariv O, Schulze E, Komitowski D, et al. The expression of the imprinted genes H19 and IGF-2 in choriocarcinoma cell lines. Is H19 a tumor suppressor gene? Oncogene. 1997;15(2):169-77. doi: 10.1038/sj.onc.1201175.

14. Wrana JL. H19, a tumour suppressing RNA? BioEssays : news and reviews in molecular, cellular and developmental biology. 1994;16(2):89-90. doi: 10.1002/bies.950160204.

15. Si H, Chen P, Li H, Wang X. Long non-coding RNA H19 regulates cell growth and metastasis via miR-138 in breast cancer. American Journal of Translational Research. 2019;11(5):3213-25.

16. Dai L, Li J, Dong Z, et al. Temporal expression and functional analysis of long non-coding RNAs in colorectal cancer initiation. Journal of Cellular and Molecular Medicine. 2019;23(6):4127-38. doi: 10.1111/jcmm.14300.

17. Gan L, Lv L, Liao S. Long non-coding RNA H19 regulates cell growth and metastasis via the miR-22-3p/Snail1 axis in gastric cancer. Int J Oncol. 2019;54(6):2157-68. doi: 10.3892/ijo.2019.4773.

18. Mahmoudian-Sani MR, Jalali A, Jamshidi M, et al. Long Non-Coding RNAs in Thyroid Cancer: Implications for Pathogenesis, Diagnosis, and Therapy. Oncology Research and Treatment. 2019;42(3):136-42. doi: 10.1159/000495151.

19. Qi D, Wang M, Yu F. Knockdown of IncRNA-H19 inhibits cell viability, migration and invasion while promotes apoptosis via microRNA-143/RUNX2 axis in retinoblastoma. Biomedicine and Pharmacotherapy. 2019;109:798-805. doi: 10.1016/j.biopha.2018.10.096.

20. Zheng Z-H, Wu D-M, Fan S-H, Zhang Z-F, Chen G-Q, Lu J. Upregulation of miR-675-5p induced by IncRNA H19 was associated with tumor progression and development by targeting tumor suppressor p53 in non-small cell lung cancer. J Cell Biochem. 2019. doi: 10.1002/jcb.29182.

21. Wu ZR, Yan L, Liu YT, et al. Inhibition of mTORC1 by IncRNA H19 via disrupting 4E-BP1/Raptor interaction in pituitary tumours. Nat Commun. 2018;9. doi: 10.1038/s41467-018-06853-3.

22. Ge LL, Wang QL, Hu SN, Yang XA. Rs217727 polymorphism in H19 promotes cell apoptosis by regulating the expressions of H19 and the activation of its downstream signaling pathway. J Cell Physiol. 2019;234(5):7279-91. doi: 10.1002/jcp.27485.

23. Frevel MA, Sowerby SJ, Petersen GB, Reeve AE. Methylation sequencing analysis refines the region of $\mathrm{H} 19$ epimutation in Wilms tumor. The Journal of biological chemistry. 1999;274(41):29331-40. doi: 10.1074/jbc.274.41.29331.

24. lyer MK, Niknafs YS, Malik R, et al. The landscape of long noncoding RNAs in the human transcriptome. Nat Genet. 2015;47(3):199-+. doi: 10.1038/ng.3192.

25. Fu W, Li L, Xiong SW, et al. miR-423 rs6505162 C>A polymorphism contributes to decreased Wilms tumor risk. J Cancer. 2018;9(14):2460-5. Epub 2018/07/22. doi: 10.7150/jca.24916.

26. Zhu J, Fu W, Jia W, Xia H, Liu GC, He J. Association between NER Pathway Gene Polymorphisms and Wilms Tumor Risk. Mol Ther Nucleic Acids. 2018;12:854-60. Epub 2018/08/31. doi: 10.1016/j.omtn.2018.08.002.

27. Zhu J, Jia W, Wu C, et al. Base Excision Repair Gene Polymorphisms and Wilms Tumor Susceptibility. Ebiomedicine. 2018;33:8893. Epub 2018/06/26. doi: 10.1016/j.ebiom.2018.06.018.

28. Hu C, Yang T, Pan J, et al. Associations between H19 polymorphisms and neuroblastoma risk in Chinese children. Bioscience Rep. 2019;39. doi: 10.1042/bsr20181582.

29. Liu P, Zhuo Z, Li W, et al. TP53 rs1042522 C>G polymorphism and Wilms tumor susceptibility in Chinese children: a four-center case-control study. Biosci Rep. 2019;39(1). Epub 2019/01/06. doi: 10.1042/BSR20181891.

30. Zhuo Z, Fu W, Liu J, et al. LIN28A gene polymorphisms confer Wilms tumour susceptibility: A four-centre case-control study. Journal of cellular and molecular medicine. 2019;23(10):7105-10. doi: 10.1111/jcmm.14561.

31. Fu W, Zhuo Z, Hua RX, et al. Association of KRAS and NRAS gene polymorphisms with Wilms tumor risk: a four-center casecontrol study. Aging (Albany NY). 2019;11(5):1551-63. Epub 2019/03/13. doi: 10.18632/aging.101855.

32. He J, Qiu LX, Wang MY, et al. Polymorphisms in the XPG gene and risk of gastric cancer in Chinese populations. Hum Genet. 2012;131(7):1235-44. doi: 10.1007/s00439-012-1152-8.

33. He J, Wang F, Zhu J, et al. Association of potentially functional variants in the XPG gene with neuroblastoma risk in a Chinese population. Journal of Cellular and Molecular Medicine. 2016;20(8):1481-90. doi: 10.1111/jcmm.12836.

34. Treger TD, Chowdhury T, Pritchard-Jones K, Behjati S. The genetic changes of Wilms tumour. Nat Rev Nephrol. 2019;15(4):240-51. doi: 10.1038/s41581-019-0112-0. 
35. Harati-Sadegh M, Kohan L, Teimoori B, Mehrabani M, Salimi S. The effects of placental long noncoding RNA H19 polymorphisms and promoter methylation on H19 expression in association with preeclampsia susceptibility. IUBMB Life. 2020;72(3):413-25. doi: 10.1002/iub.2199.

36. Okamoto K, Morison IM, Taniguchi T, Reeve AE. Epigenetic changes at the insulin-like growth factor II/H19 locus in developing kidney is an early event in Wilms tumorigenesis. P Natl Acad Sci USA. 1997;94(10):5367-71.

37. Yang $\mathrm{M}, \mathrm{He} \mathrm{T}$, Jiang $\mathrm{L}$, et al. The role of maternal methylation in the association between prenatal meteorological conditions and neonatal H19/H19-DMR methylation. Ecotox Environ Safe. 2020;197:110643. doi: 10.1016/j.ecoenv.2020.110643.

38. Gao T, He B, Pan Y, et al. H19 DMR methylation correlates to the progression of esophageal squamous cell carcinoma through IGF2 imprinting pathway. Clinical \& translational oncology : official publication of the Federation of Spanish Oncology Societies and of the National Cancer Institute of Mexico. 2014;16(4):410-7. doi: 10.1007/s12094-013-1098-x.

39. Coorens THH, Treger TD, Al-Saadi R, et al. Embryonal precursors of Wilms tumor. Science (New York, NY). 2019;366(6470):124751. doi: 10.1126/science.aax1323.

40. Marjonen H, Auvinen P, Kahila H, et al. rs10732516 polymorphism at the locus associates with genotype-specific effects on placental DNA methylation and birth weight of newborns conceived by assisted reproductive technology. Clin Epigenetics. 2018;10:80. doi: 10.1186/s13148-018-0511-2.

41. Scacalossi KR, van Solingen C, Moore KJ. Long non-coding RNAs regulating macrophage functions in homeostasis and disease. Vascular Pharmacology. 2019;114:122-30. doi: 10.1016/j.vph.2018.02.011.

42. Do H, Kim W. Roles of Oncogenic Long Non-coding RNAs in Cancer Development. Genomics Inform. 2018;16(4):e18. Epub 2019/01/03. doi: 10.5808/GI.2018.16.4.e18.

43. Fatica A, Bozzoni I. Long non-coding RNAs: new players in cell differentiation and development. Nat Rev Genet. 2014;15(1):7-21. Epub 2013/12/04. doi: 10.1038/nrg3606.

44. Wang X, Wang $X$, Zhao P, Chen W, Wu H, Wei M. Research progress of H19 gene in the field of tumor research. Fudan University Journal of Medical Sciences. 2017;44(2):224-30.

45. Hashemi M, Moazeni-Roodi A, Sarabandi S, Karami S, Ghavami S. Association between genetic polymorphisms of long noncoding RNA H19 and cancer risk: a meta-analysis. Journal of Genetics. 2019;98(3). doi: 10.1007/s12041-019-1126-x.

46. Luo M, Li Z, Wang W, Zeng Y, Liu Z, Qiu J. Long non-coding RNA H19 increases bladder cancer metastasis by associating with EZH2 and inhibiting E-cadherin expression. Cancer letters. 2013;333(2):213-21. doi: 10.1016/j.canlet.2013.01.033.

47. Yoshimura $H$, Matsuda $Y$, Yamamoto $M$, et al. Reduced expression of the $H 19$ long non-coding RNA inhibits pancreatic cancer metastasis. Laboratory investigation; a journal of technical methods and pathology. 2018;98(6):814-24. doi: 10.1038/s41374018-0048-1.

48. Ren J, Ding L, Zhang D, et al. Carcinoma-associated fibroblasts promote the stemness and chemoresistance of colorectal cancer by transferring exosomal IncRNA H19. Theranostics. 2018;8(14):3932-48. doi: 10.7150/thno.25541.

49. Wang L, Cai Y, Zhao X, et al. Down-regulated long non-coding RNA H19 inhibits carcinogenesis of renal cell carcinoma. Neoplasma. 2015;62(3):412-8. Epub 2015/04/14. doi: 10.4149/neo_2015_049.

50. Li S, Hua Y, Jin J, et al. Association of genetic variants in IncRNA H19 with risk of colorectal cancer in a Chinese population. Oncotarget. 2016;7(18):25470-7. doi: 10.18632/oncotarget.8330.

51. Verhaegh GW, Verkleij L, Vermeulen SHHM, den Heijer M, Witjes JA, Kiemeney LA. Polymorphisms in the H19 Gene and the Risk of Bladder Cancer. European Urology. 2008;54(5):1118-26. doi: 10.1016/j.eururo.2008.01.060.

52. Xia Z, Yan R, Duan F, Song C, Wang P, Wang K. Genetic Polymorphisms in Long Noncoding RNA H19 Are Associated With Susceptibility to Breast Cancer in Chinese Population. Medicine. 2016;95(7). doi: 10.1097/md.0000000000002771.

53. Qi P, Du X. The long non-coding RNAs, a new cancer diagnostic and therapeutic gold mine. Modern Pathol. 2013;26(2):155-65. doi: 10.1038/modpathol.2012.160.

54. Cai $X$, Cullen BR. The imprinted H19 noncoding RNA is a primary microRNA precursor. RNA. 2007;13(3):313-6. doi: $10.1261 /$ rna.351707.

55. Li H, Li J, Jia S, et al. miR675 upregulates long noncoding RNA H19 through activating EGR1 in human liver cancer. Oncotarget. 2015;6(31):31958-84. doi: 10.18632/oncotarget.5579. 
56. Wu T, Qu L, He G, et al. Regulation of laryngeal squamous cell cancer progression by the IncRNA H19/miR-148a-3p/DNMT1 axis. Oncotarget. 2016;7(10):11553-66. Epub 2016/02/13. doi: 10.18632/oncotarget.7270.

57. Li H, Yu B, Li J, et al. Overexpression of IncRNA H19 enhances carcinogenesis and metastasis of gastric cancer. Oncotarget. 2014;5(8):2318-29. Epub 2014/05/09. doi: 10.18632/oncotarget.1913.

58. Lin Y, Fu F, Chen Y, et al. Genetic variants in long noncoding RNA H19 contribute to the risk of breast cancer in a southeast China Han population. Oncotargets and Therapy. 2017;10:4369-78. doi: 10.2147/ott.S127962.

59. Hua QH, Lv X, Gu X, et al. Genetic variants in IncRNA H19 are associated with the risk of bladder cancer in a Chinese population. Mutagenesis. 2016;31(5):531-8. doi: 10.1093/mutage/gew018.

60. Gao W, Zhu M, Wang H, et al. Association of polymorphisms in long non-coding RNA H19 with coronary artery disease risk in a Chinese population. Mutation Research-Fundamental and Molecular Mechanisms of Mutagenesis. 2015;772:15-22. doi: 10.1016/j.mrfmmm.2014.12.009.

61. Yang C, Tang R, Ma X, et al. Tag SNPs in long non-coding RNA H19 contribute to susceptibility to gastric cancer in the Chinese Han population. Oncotarget. 2015;6(17):15311-20. doi: 10.18632/oncotarget.3840.

\section{Supplementary Files}

This is a list of supplementary files associated with this preprint. Click to download.

- SupplementalTable1Feb4.doc 